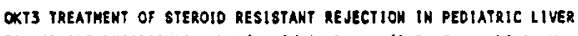

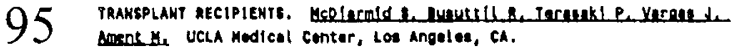

The auccess of oxis in revereing rejoction in a podiatele liver transplentation aeries has not been previously roported. Of - total of 187 coneceut ive liver grafts In 149 pedfatric patients transplanted at UCLA Medical Conter, s9 episodes of eteroid resiatent, biopsy proven, refection (32X of grafta), were ireated with OKI3. OKI3 was

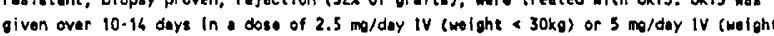
given over $10-16$ days in a dost of $2.5 \mathrm{mg} / \mathrm{day}$ iv (woight \& 30kg) or $3 \mathrm{mg} / \mathrm{day}$ iv (weight

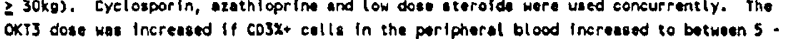
OKI3 dose was Increased If CO3X+ calls in the periphersl blood increased to betwoen bltirubin and transeminases by 50x), or tellure (no improvement). BEsults; After axt3 trostment IIver function was normal in 60x; improved in 35x; and unchanged in 25x. Of 21 perticl responses, 12 opteodes oventually resolved to yietd en overall fult response rate of 5ox. The oraft survival of 12 grafts falling is apleodes of oxi3 treetmant waes 27x. CD3X $\geq 3 x$ oceurred durine $61 X$ of OKT3 treatment coursets. 6 greafte were retreesed titi arrs ind in ell cosx could noe me

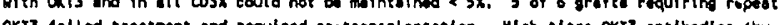

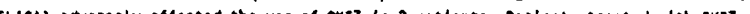

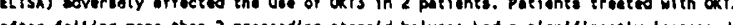
after falline more than 2 procoodino atorold bolusee had a el gnifitently Increased chance of orart loss (57x, $p=0.01$ ). Oraft aurvival (70X) and petiont ourvival (85x) in OKT3 trentod pat lente was no differont from graft and patlent survival for all other

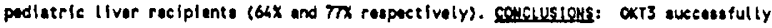
reacued grafte with storold reelssant rojection, and wae nost offective when given -eriy. Our group of pedistrle potionte sppeared lese reaponeive to OKi3 compered to

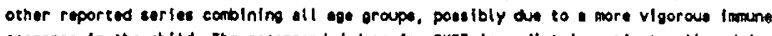
response in the chitd. The recomended dose for OKTs in pediatric partients allowed for the re-emergence of $\mathrm{COS}_{+}$cells in the mejority. Higher doses of OKT3 may Improve the eftleacy of oxt3 in podiatric pationte.
PREDIABETIC INDICES IN CHILDREN WITH CLUTEN
96 SENSITIVITY ENTEROPATHY (GSE)
T. Karag1ozoglou, P. Augoustides, . Nousia-Arvenitakis
Dept of Pediatrics, Univ of Thessaloniki, Greoce This is a prospective study of insulin secretion and immunologic changes in a group of children with GSE on gluten froe diet. The purpose of the study is to investigate the possible association of disturbances of insulin secretion with the inc1dence of insulin dependent diabetes mellitus (IDDM) which is known to be high in GSE. Thirty patients, 4 to 18 years old, were examined. They underwent IV glucose tolerence test during which glucose disappesrance rate $(K)$ and first phase insulin response (I i 3) were meesured. Typing for HLA A,B,C and DR antigens was performed (ICA) on two occasions. Pancrestic 1soenylase (PIA) was messured as an index of exocrine pancreatic function. The same procedureg procedures were performed on 30 healthy children. The results are as rollows: $a$ ) In $24 \%$ of celiac chlldren $I_{i+3}$ and $K$ rate were decreased. b) There was significant correlation between the two parameters $(p<0,01), c)$ The incidence of HLA $B_{8}$ and $D_{3}$ wes higher in GSE (33\% and $60 \%$, respectively) then in herlthy individuals $(6,6 \%$ and $20 \%$, respectively).d) All patients were found to be ICA negative at the time of the study. $\theta$ ) There was no correlation between parameters of endocrine $\left(I_{1}+3_{i} \mathrm{~K}\right.$ rate $)$ and exocrine pancreatic function (PIA). Conclusions: Al though there was no ovidence of lalet cell immune destruction at the time of the study, a decline of first phase insuin secretion was indeed documented. Th1s decline may be an expression of a prodlabetic phase. HLA $B_{\text {and }} \mathrm{DR}_{3}$ which are detacted in collac patients may indicate a possiblo common pathogenetic mechanlsm between GSE and IDDM.

\title{
Author Index to Abstracts
}

\author{
(Numbers cited refer to abstract numbers)
}

Adriantsoa M, 26

Ahlstedt S, 32

A-Kader $\mathrm{HH}, 78$

Albano F, 49

Alessio M, 49

Ament M, 95

Ament MA, 84

Ament ME, 81, 82

Andre FE, 37

Apostolo MG, 42

Arato A, 25

Arco A, 40

Arco Alba, 40

Arena $\mathrm{F}, 40$

Arvilommi H, 5

Augoustides P, 96

Auricchio S, 18, 19, 20, 35

Baldassarre M, 35

Balistreri WF, 78

Ballabio A, 20

Ballati G, 45

Barbet JP, 31

Barresi G, 40

Baudry B, 15

Baumann W, 16

Belli DC, 3

Berger HM, 53

Berkowitz D, 78

Bernardo I, 48

Bevin L, 6

Bhan MK, 9

Bhutta ZA, 91

Bijman J, 21, 54

Billingsley GD, 70

Bishop WP, 83

Bisset MW, 12

Boll W, 20

Bonamico M, 45

Booth IW, 30

Borchard F, 44

Bouquet J, 21, 54

Bourdelat D, 31

Boutton TW, 64

Brill J, 81

Brousse N, 46
Brueton MJ, 24

Bucuvalas J, 77

Buikhuisen WA, 75

Büller HA, 8, 74, 94

Burdelski M, 36

Burrin DG, 88

Busuttil R, 81, 95

Butcher PD, 51

Butler-Browne GS, 31

Buts JP, 1, 17

Butte NF, 65, 66, 68

Cadranel S, 37, 38

Canani RB, 48

Capella C, 18

Carlier M, 17

Carrazza FR, 67

Carreño V, 39

Caseseca T, 11

Castellani MR, 42

Cerf-Bensussan N, 46

Cevallos AM, 51

Chew F, 64

Chin S, 56

Chu S-hW, 93

Cleghorn G, 56

Cohen MB, 72, 73

Colombo C, 42

Conlon M, 86

Cordano A, 67

Corey M, 79

Cornaggia M, 18, 19

Cox DW, 70

Crain-Denoyelle AM, 26

Cucchiara S, 35

D'Alessandro D, 45

Daum F, 87

Davis TP, 60

Dayer JM, 3

de Jonge HR, 21, 54

De Potter S, 46

Desjeux JF, 26

de Ville de Goyet J, 17

De Vizia B, 20
Diver-Haber A, 50

Ducroc R, 27

Dudley MA, 63, 69

Dumaswala R, 77

Dupont C, 31

Dupuis C, 58

Durie P, 79

Durie PR, 71

Duthie A, 6

Düwel J, 36

Eade MN, 72

Eichelbaum M, 44

Ellis LE, 71

Espersen F, 10

Evans CM, 90

Fällström SP, 32

Farthing MJG, 51

Fasano A, 14, 15

Ferrante E, 45

Finkel $Y, 30$

Finzi G, 18, 19

Fiocca $R, 18,19$

Fisher S, 87

Flick JA, 71

Flores-Huerta S, 65, 66

Foote KD, 55

Forman S, 42

Fransen J, 23

Freeman KL, 88

Freier S, 13

Frost JD Jr, 68

Fuller R, 85

García-Aguado J, 39

Garlick PJ, 24

Garza C, 65

Garzon B, 27

Gaudreault P, 58

Geloso JP, 27

Giannella RA, 72, 73

Giorgio I, 35

Giunta A, 42

Glaze DG, 68
Goldman DA, 8

Gothefors L, 29

Goulet O, 46

Goyens P, 38

Goyvaerts $\mathrm{H}, 2$

Grand RJ, 8, 74, 94

Gremse DA, 78

Griffiths H, 53

Guandalini S, 48

Guarino A, 48, 49

Guss W, 84

Guzzetta V, 20

Halley DJJ, 21

Harrison R, 81

Hart MH, 89

Harty R, 89

Haschke F, 52

Hauri H-P, 23

Heinz-Erian P, 47

Helven R, 2

Heubi JE, 80

Heyman M, 26

Hill SM, 11

Holm S, 29

Houwen RHJ, 70

Ho WM, 18

Huemer C, 52

Huemer KH, 52

Hueter A, 16

Hyndman V, 76

Innis SM, 55

Isolauri $\mathrm{E}, 4,5$

Jafusco M, 48

Jalonen T, 4, 5

Janas M, 33

Jan D, 46

Jenkins HR, 12, 30

Jensen CL, 68

Jensen NJ, 73

Johnston P, 69

Jonas A, 50

Jones $\mathrm{H}, 6$ 